\title{
ANALISIS PERMINTAAN DAN PREDIKSI KONSUMSI SERTA PRODUKSI DAGING BROILER DI KOTA KENDARI PROPINSI SULAWESI TENGGARA
}

\section{DEMAND AND CONSUMPTION ANALYSIS AND BROILER MEAT PRODUCTION IN KENDARI CITY, SOUTHEAST SULAWESI}

\author{
Hairil Adzulyatno Hadini ${ }^{1 *}$, Sudi Nurtini ${ }^{2}$, dan Endang Sulastri ${ }^{2}$ \\ ${ }^{1}$ Jurusan Peternakan, Fakultas Pertanian, Universitas Haluoleo, Kendari, 93232 \\ ${ }^{2}$ Fakultas Peternakan, Universitas Gadjah Mada, Jl. Fauna No. 3, Bulaksumur, Yogyakarta, 55281
}

\section{INTISARI}

Penelitian dengan tujuan untuk mengetahui faktor-faktor yang mempengaruhi permintaan daging broiler di Kota Kendari, mengetahui respon (elastisitas) jumlah penduduk, pendapatan, harga daging broiler, daging sapi, daging ayam buras, telur, ikan bandeng, minyak goreng, beras dan kejadian flu burung terhadap perubahan permintaan daging broiler, dan memprediksi kebutuhan daging broiler di Kota Kendari. Penentuan lokasi dilakukan secara sengaja berdasarkan populasi terbesar. Metode penelitian adalah deskriptif analisis menggunakan data sekunder (time series) tahun1994-2008 meliputi jumlah penduduk, pendapatan, harga daging broiler, daging sapi, daging ayam buras, telur, ikan bandeng, minyak goreng dan beras. Estimasi fungsi permintaan menggunakan analisis Regresi Linier Berganda dalam logaritma. Hasil analisis regresi menunjukkan bahwa secara bersama-sama variabel independen memberikan pengaruh signifikan $(\mathrm{P}<0,01)$ terhadap variabel dependen dengan nilai $\mathrm{R}^{2}$ sebesar 0,9804 . Secara parsial jumlah penduduk, pendapatan, harga daging broiler, harga daging sapi, harga telur, harga ikan bandeng, harga minyak goreng dan harga beras, masing-masing berpengaruh terhadap permintaan daging broiler. Prediksi konsumsi daging broiler tahun 2015 mencapai $428.463 \mathrm{~kg}$. Peningkatan jumlah penduduk, pendapatan perkapita, harga daging sapi dan ikan bandeng dapat menyebabkan meningkatnya permintaan daging broiler. Peningkatan harga daging broiler, minyak goreng dan beras dapat menurunkan permintaan daging broiler. Elastisitas pendapatan terhadap permintaan daging broiler masyarakat Kota Kendari bernilai positif dan kurang dari satu, menunjukkan bahwa daging broiler termasuk barang superior yang merupakan barang kebutuhan pokok. Elastisitas harga daging broiler sendiri bersifat inelastis yang menunjukkan daging broiler merupakan barang kebutuhan pokok. Daging broiler merupakan barang substitusi bagi daging sapi dan ikan bandeng, sedangkan minyak goreng dan beras termasuk barang komplementer. Perkembangan konsumsi daging broiler cenderung mengalami peningkatan, seiring dengan bertambahnya waktu dan jumlah penduduk.

(Kata kunci: Permintaan, Daging broiler, Elastisitas)

\section{ABSTRACT}

The objectives of research were to determine the factors that affected to demand of broiler meat in Kendari city, to obtain the response (elasticity) of population, income, price of boiler meat, beef, free-range chicken meat, eggs, bandeng, cooking oil, rice and occurrence of avian influenza on changes in demand of broiler meat, and to predict the demand of broiler meat in Kendari city. The location was selected based on its highest population. The method used in this research was a descriptive analysis using time series data (1994-2008) covering population, income, price of broiler meat, beef, free-range chicken meat, eggs, bandeng, cooking oil and rice. The demand was estimated by a demand function approach using multiple linear regressions in logarithm. Regression analysis result showed that independent variable collectively affected significantly $(P<0.01)$ on dependent variable with $R$ value 0,9804. Partially, the amount of population, income, the price of broiler meat, the price of beef, the price of bandeng, the price of cooking oil, the price of rice influence broiler meat's demand. Prediction of broiler meat consumption in 2015 is $428,463 \mathrm{~kg}$. Population increase, per income capita, beef price and bandeng price increase can affect broiler meat demand. Broiler meat price, cooking oil price and rice price increase can reduce broiler chicken demand. Income elasticity of Kendari city Population on broiler chicken demand has positive value and less than one, which shows that broiler meat is one of primary needs. Functionally, broiler meat is a substitute goods for beef and bandeng, whereas cooking oil and rice are complementary goods. Trend of broiler meats consumption increasing, with time and population.

(Key words: Demand, Broiler meat, Elasticity)

\footnotetext{
* Korespondensi (corresponding author):

Telp.+62 85656532 030, E-mail: zhadini@yahoo.com
} 


\section{Pendahuluan}

Peningkatan populasi penduduk dan perbaikan taraf hidup masyarakat menyebabkan permintaan terhadap berbagai kebutuhan bahan pangan terus meningkat. Pola konsumsi menu makanan rumah tangga juga secara bertahap mengalami perubahan kearah peningkatan konsumsi protein hewani (termasuk produk peternakan).

Faktor pendorong meningkatnya permintaan tersebut secara teoritis disebut dengan demand shifter, yaitu faktor yang mempengaruhi atau mengakibatkan adanya perubahan permintaan (Pappas dan Hirschey, 1995). Soedjana (1996) mengemukakan bahwa tingkat permintaan produk ternak seperti daging dan telur dipengaruhi oleh harga produk itu sendiri, produk substitusinya maupun komplementernya, tingkat pendapatan rumah tangga serta preferensi konsumen terhadap berbagai pilihan produk yang tersedia.

Salah satu produk daging sebagai protein hewani yang diminati masyarakat Kota Kendari adalah daging broiler. Harga daging broiler cenderung tinggi dan berfluktuasi, hal tersebut tidak hanya terjadi pada daging broiler, tetapi juga terjadi pada komoditas lainnya seperti telur, ikan, daging sapi, daging kerbau, dan daging kambing. Hal ini merupakan salah satu penyebab masih rendahnya tingkat konsumsi daging masyarakat Indonesia.

Banyak faktor yang mempengaruhi permintaan daging broiler. Jumlah permintaan daging broiler tidak hanya dipengaruhi oleh harga daging ayam itu sendiri, tetapi dipengaruhi oleh harga barang-barang lain seperti harga daging sapi, daging ayam buras, ikan, minyak goreng, beras, jumlah penduduk, tingkat pendapatan konsumen yang mencerminkan daya beli, dan kejadian flu burung. Faktor ekonomi dan non ekonomi tersebut secara bersama-sama mempengaruhi perilaku konsumen. Pengetahuan tentang faktor-faktor yang mempengaruhi permintaan daging broiler, juga diperlukan prediksi kebutuhan daging broiler pada masa yang akan datang.

Berdasarkan hal-hal yang dikemukakan di atas maka dipandang perlu untuk melakukan penelitian tentang analisis permintaan serta prediksi konsumsi dan produksi daging broiler di Kota Kendari. Penelitian ini bertujuan untuk 1) mengetahui faktor-faktor yang mempengaruhi permintaan daging broiler di Kota Kendari; 2) mengetahui respon (elastisitas) jumlah penduduk, pendapatan masyarakat, harga daging broiler, harga daging sapi, harga daging ayam buras, harga telur, harga ikan bandeng, harga minyak goreng, harga beras dan kejadian flu burung terhadap perubahan permintaan daging broiler; dan 3) memprediksi kebutuhan daging broiler di Kota Kendari.

\section{Materi dan Metode}

Pelaksanaan penelitian dilaksanakan di Kota Kendari Provinsi Sulawesi Tenggara. Penentuan lokasi dilakukan secara sengaja (purposive) didasarkan pada populasi ayam broiler di Sulawesi Tenggara masih terpusat di Kota Kendari.

Jenis data penelitian berupa data sekunder (time series) selama 15 tahun dari tahun 1994 sampai tahun 2008, meliputi: permintaan daging broiler (kg), jumlah penduduk (jiwa), pendapatan $(\mathrm{Rp} / \mathrm{kapita})$, harga daging broiler $(\mathrm{Rp} / \mathrm{kg})$, harga daging sapi $(\mathrm{Rp} / \mathrm{kg})$, harga daging ayam buras $(\mathrm{Rp} / \mathrm{kg})$, harga ikan bandeng $(\mathrm{Rp} / \mathrm{kg})$, harga telur $(\mathrm{Rp} /$ butir), harga minyak goreng (Rp/liter) dan harga beras $(\mathrm{Rp} / \mathrm{kg})$. Data diperoleh dari Badan Pusat Statistik (BPS) dan Dinas Pertanian, Kehutanan dan Peternakan Kota Kendari.

Fungsi permintaan daging broiler diestimasi menggunakan analisis Regresi Linier Berganda dalam logaritma (Gujarati, 1999). Secara matematis fungsi permintaan daging broiler dirumuskan sebagai berikut:

$$
\begin{aligned}
\ln Q d= & \ln \alpha+b_{1} \ln X_{1}+b_{2} \ln X_{2}+b_{3} \ln X_{3}+b_{4} \ln \\
& X_{4}+b_{5} \ln X_{5}+b_{6} \ln X_{6}+b_{7} \ln X_{7}+b_{8} \ln \\
& X_{8}+b_{9} \ln X_{9}+D+e
\end{aligned}
$$

\section{Keterangan:}

$\mathrm{Qd}=$ jumlah permintaan daging broiler $(\mathrm{kg})$

$\alpha \quad=$ konstanta atau intersep

b1-b9 = koefisien regresi masing-masing variabel

$\mathrm{X}_{1} \quad$ = jumlah penduduk (jiwa)

$\mathrm{X}_{2} \quad=$ pendapatan (Rp/kapita)

$\mathrm{X}_{3} \quad=$ harga daging broiler $(\mathrm{Rp} / \mathrm{kg})$

$\mathrm{X}_{4} \quad=$ harga daging sapi $(\mathrm{Rp} / \mathrm{kg})$

$\mathrm{X}_{5} \quad=$ harga daging ayam buras $(\mathrm{Rp} / \mathrm{kg})$

$\mathrm{X}_{6} \quad=$ harga ikan bandeng $(\mathrm{Rp} / \mathrm{kg})$

$\mathrm{X}_{7} \quad$ = harga telur ayam ras (Rp/butir)

$\mathrm{X}_{8} \quad$ = harga minyak goreng $(\mathrm{Rp} /$ liter $)$

$\mathrm{X}_{9} \quad=$ harga beras $(\mathrm{Rp} / \mathrm{kg})$

$\mathrm{D}_{1} \quad=$ kejadian flu burung (variabel dummy)

$1=$ sebelum terjadi flu burung

$0 \quad=$ sesudah terjadi flu burung

$\mathrm{e} \quad=$ tingkat kesalahan

Prediksi produksi dan konsumsi daging broiler di Kota Kendari tahun 2009-2015 diprediksi dengan menggunakan persamaan garis linier untuk mendapatkan garis trend, yang secara matematis dapat ditulis sebagai berikut (Saleh, 2004):

$$
\mathrm{C}=\mathrm{a}+\mathrm{bX}
$$

Keterangan: $\mathrm{C}=$ nilai trend yang akan dihitung, $\mathrm{a}=$ nilai trend pada tahun dasar tertentu, $\mathrm{b}=$ besarnya pertambahan trend pertahun dan $\mathrm{X}=$ unit tahun. 


\section{Hasil dan Pembahasan}

\section{Analisis permintaan daging broiler}

Hasil analisis regresi pada tabel menunjukkan bahwa variabel independen (jumlah penduduk, pendapatan, harga daging broiler, harga daging sapi, harga ayam buras, harga ikan bandeng, harga telur, harga minyak goreng, harga beras dan kejadian flu burung) berpengaruh terhadap variabel dependen (permintaan daging broiler).

Hasil analisis pada tabel diperoleh nilai Fhitung sebesar 197.2 dan nilai tersebut lebih besar dari nilai F-tabel $(7,720)$. Hal ini berarti bahwa pengaruh variabel independen secara bersama-sama terhadap permintaan daging broiler signifikan pada tingkat kepercayaan $99 \%$.

Hasil analisis regresi diperoleh nilai $\mathrm{R}^{2}$ sebesar 0,9804. Hal ini berarti bahwa 98,04\% variasi variabel dependen (permintaan daging broiler di Kota Kendari) dapat dijelaskan secara bersama-sama oleh variabel independen yang diteliti, sedangkan sisanya sebesar $1,96 \%$ dijelaskan oleh variabel lain yang tidak diteliti pada penelitian, sehingga model regresi fungsi permintaan daging broiler di Kota Kendari sangat cocok untuk digunakan.

\section{Jumlah penduduk}

Jumlah penduduk yang berubah berpengaruh terhadap jumlah barang yang diminta. Jumlah penduduk yang besar merupakan pasar yang potensial untuk memasarkan suatu produk termasuk produk hasil peternakan. Hasil analisis regresi memperlihatkan bahwa variabel jumlah penduduk menunjukkan adanya pengaruh yang signifikan terhadap permintaan daging broiler di Kota Kendari pada tingkat kepercayaan 95\%. Besarnya nilai koefisien regresi variabel jumlah penduduk adalah 3,23 . Hal ini berarti bila jumlah penduduk bertambah $1 \%$, sedangkan faktor lain dianggap tetap, maka jumlah permintaan daging broiler di Kota Kendari mengalami peningkatan sebesar 3,23\%.

\section{Pendapatan}

Pendapatan merupakan salah satu faktor penentu dalam permintaan suatu barang. Untuk barang superior berlaku hukum apabila pendapatan meningkat, maka masyarakat/konsumen akan meningkatkan permintaannya (efek pendapatan positif). Untuk barang inferior, dengan kenaikan pendapatan akan menurunkan permintaan barang itu (efek pendapatan negatif). Hasil analisis regresi pada tabel memperlihatkan bahwa pendapatan menunjukkan adanya pengaruh yang signifikan terhadap jumlah permintaan daging broiler di Kota Kendari pada tingkat kepercayaan 99\%.

Koefisien regresi variabel pendapatan adalah 0,83 . Hal ini berarti jika pendapatan masyarakat meningkat sebesar $1 \%$ sedangkan faktor lain dianggap tetap, maka permintaan daging broiler meningkat sebesar $0,83 \%$. Nilai elastisitas dari variabel pendapatan adalah sebesar 0,83 yang berarti daging broiler di Kota Kendari termasuk barang superior yang merupakan barang kebutuhan pokok.

\section{Harga daging broiler}

Hukum permintaan suatu barang berlaku bahwa perubahan harga suatu barang menyebabkan perubahan jumlah barang yang diminta. Hasil

Tabel hasil analisis regresi permintaan daging broiler di Kota Kendari tahun 1994 - 2008 (result of regression analysis of broiler meat demand in Kendari from 1994 to 2008)

\begin{tabular}{lccc}
\hline \hline \multicolumn{1}{c}{ Variabel independen (independent variable) } & Koef. regresi & t-hitung & Sig \\
\hline Konstanta (constante) & $-37,94^{* * *}$ & -3.347 & 0,003 \\
Jumlah penduduk (population) & $3.23^{* *}$ & 2,683 & 0,015 \\
Pendapatan (income) & $0.83^{* * *}$ & 3,266 & 0,004 \\
Harga daging broiler (broiler meat price) & $-0,99^{* * *}$ & $-2,289$ & 0,008 \\
Harga daging sapi (beef price) & $1.12^{* *}$ & 2,755 & 0,013 \\
Harga daging ayam buras (native chicken meat price) & $-0,70^{\mathrm{ns}}$ & $-1,273$ & 0,218 \\
Harga ikan bandeng (bandeng price) & $1.17^{* * *}$ & 4,171 & 0,001 \\
Harga telur (egg price) & $0,71^{\mathrm{ns}}$ & 1,659 & 0,113 \\
Harga minyak goreng (fried oil price) & $-0,61^{*}$ & $-1,936$ & 0,068 \\
Harga beras (rice price) & $-0,73^{* *}$ & $-2,131$ & 0,046 \\
Kejadian flu burung (dummy) (bird flose case) & $-0,01^{\mathrm{ns}}$ & $-0,031$ & 0,975 \\
\hline Koefisien determinasi $\left(\mathrm{R}^{2}\right)$ & 0,9804 & 0,000 & \\
F hitung & $197,2^{* * *}$ & & \\
\hline
\end{tabular}

*** Signifikan pada tingkat kepercayaan $99 \%, * *$ Signifikan pada tingkat kepercayaan $95 \%, *$ Signifikan pada tingkat kepercayaan $90 \%,{ }^{\text {ns }}$ non significant. 
analisis regresi menunjukkan bahwa variabel harga daging broiler memperlihatkan pengaruh negatif dan signifikan terhadap permintaan daging broiler di Kota Kendari pada tingkat kepercayaan 99\% dengan nilai koefisien regresi sebesar -0,99. Hal ini menunjukkan bahwa apabila harga daging broiler mengalami kenaikan sebesar $1 \%$ sedangkan faktor lain dianggap tetap, maka permintaan daging broiler di Kota Kendari mengalami penurunan sebesar $0,99 \%$.

Variabel harga daging broiler itu sendiri mengikuti hukum permintaan, yaitu jika harga daging broiler naik maka permintaan daging broiler mengalami penurunan dan sebaliknya. Jika koefisien regresi dianggap sebagai elastisitas harga sendiri terhadap permintaan daging broiler dengan nilai lebih kecil dari 1 , berarti bahwa perubahan harga daging broiler terhadap jumlah permintaan daging broiler kurang responsif terhadap perubahan harga di pasar, sehingga elastisitas harga daging broiler terhadap jumlah permintaan bersifat in elastis yang berarti daging broiler merupakan barang kebutuhan pokok.

Hasil penelitian sejalan dengan temuan Nurtini et al. (1998) yang menginformasikan bahwa variabel daging broiler mempunyai koefisien elastisitas harga terhadap permintaan kurang dari satu (in elastis), sehingga merupakan barang kebutuhan pokok, tetapi berbeda dengan penelitian Wahyudi (2002) bahwa perubahan harga daging ayam ras terhadap jumlah permintaan daging ayam ras bersifat elastis atau merupakan barang mewah. Perbedaan ini disebabkan karena pada tahun tersebut (2002) belum lama terjadi krisis ekonomi yang menyebabkan harga daging broiler masih relatif tinggi bagi konsumen.

\section{Harga daging sapi}

Koefisien variabel harga daging sapi menunjukkan adanya pengaruh positif dan signifikan terhadap permintaan daging broiler pada tingkat kepercayaan $95 \%$, yang berarti bahwa perubahan harga daging sapi di pasar dapat mempengaruhi permintaan daging broiler di Kota Kendari. Besarnya nilai koefisien regresi harga daging sapi adalah sebesar 1,12. Koefisien variabel positif dapat diartikan jika harga daging sapi mengalami kenaikan $1 \%$ sedangkan faktor lain dianggap tetap, maka permintaan daging broiler akan mengalami peningkatan sebesar $1,12 \%$. Dengan demikian, pengaruh perubahan harga daging sapi terhadap permintaan daging broiler sangat responsif. Jika koefisien regresi diartikan sebagai elastisitas dari variabel harga daging sapi yang merupakan elastisitas silang terhadap jumlah permintaan daging broiler dengan nilai positif $(1,12)$, maka daging broiler di Kota Kendari bersifat substitusi bagi daging sapi, sehingga apabila harga daging sapi meningkat maka daging sapi dapat digantikan penggunaannya oleh daging broiler. Hal ini dapat terjadi karena keduanya termasuk kelompok pangan hewani dan penggunaannya tergantung pada pendapatan yang dimiliki.

\section{Harga daging ayam buras}

Koefisien variabel harga daging ayam buras tidak menunjukkan adanya pengaruh yang signifikan terhadap permintaan daging ayam broiler, yang berarti bahwa perubahan harga daging ayam buras tidak mempengaruhi permintaan daging broiler. Hal ini sesuai dengan hasil penelitian Nurtini et al. (1998) yang melaporkan bahwa pada golongan pendapatan tinggi yang relatif lebih memiliki kemampuan memilih, mereka lebih memilih daging ayam buras dari pada daging broiler.

Masyarakat golongan pendapatan tinggi selain selera, preferensi kesehatan menjadi alasan untuk memilih daging ayam buras karena mempunyai kandungan lemak yang lebih rendah jika dibandingkan dengan ayam broiler, juga untuk memenuhi tuntutan tambahan atribut seperti rasa yang enak, kualitas dan kandungan nutrisi. Masyarakat golongan pendapatan rendah dan menengah cenderung memilih daging broiler karena harga lebih murah dan ketersediaannya di pasaran.

\section{Harga ikan bandeng}

Hasil analisis regresi menunjukkan bahwa variabel harga ikan memberikan pengaruh yang signifikan terhadap permintaan daging broiler di kota Kendari pada tingkat kepercayaan 99\%. Koefisien variabel harga ikan bandeng adalah sebesar 1,17. Hal ini berarti bahwa bila harga ikan mengalami kenaikan sebesar $1 \%$ sedangkan faktor lain dianggap tetap, maka permintaan daging broiler akan mengalami kenaikan sebesar 1,17\%.

Elastisitas harga ikan bandeng terhadap permintaan daging broiler bernilai positif, menunjukkan bahwa daging broiler bersifat substitusi terhadap ikan bandeng. Hal ini dapat terjadi karena keduanya termasuk kelompok pangan hewani sehingga memungkinkan konsumen untuk beralih mengkonsumsi ikan bandeng ke daging broiler, apabila harga ikan bandeng meningkat. Hasil penelitian sesuai hasil penelitian Rusman dan Suharyanto (2004) di Sulawesi Tenggara namun berbeda dengan hasil penelitian Wahyudi (2002) di Jogjakarta. Perbedaan ini terkait dengan kondisi wilayah dan karateristik masyarakat setempat. Kota Kendari merupakan daerah wilayah pesisir dengan ketersediaan ikan yang cukup dan kebiasaan makan ikan, sedangkan Jogjakarta sebagian besar wilayahnya bukan daerah pesisir dan selera masyarakat terhadap ikan kurang. 


\section{Harga telur}

Variabel harga telur tidak menunjukkan adanya pengaruh yang signifikan terhadap permintaan daging broiler di Kota Kendari, berarti bahwa naik turunnya harga telur tidak mempengaruhi permintaan daging broiler. Masyarakat Kota Kendari telur pada umumnya digunakan sebagai bahan baku dalam pembuatan kue dan industri pangan lainnya.

\section{Harga minyak goreng}

Variabel harga minyak goreng menunjukkan pengaruh yang signifikan terhadap permintaan daging broiler di Kota Kendari pada tingkat kepercayaan $90 \%$. Artinya tinggi rendahnya harga minyak goreng di pasar akan mempengaruhi permintaan daging broiler. Koefisien regresi variabel minyak goreng adalah sebesar $-0,61$, dan jika koefisien regresi diartikan sebagai elastisitas harga silang, maka minyak goreng termasuk barang komplementer terhadap daging broiler.

Koefisien regresi negatif $(-0,61)$ memberikan pengertian bahwa kenaikan $1 \%$ harga minyak goreng dengan anggapan barang lain tetap maka akan diikuti dengan penurunan jumlah permintaan ayam broiler sebesar $0,61 \%$. Minyak goreng merupakan salah satu bahan yang digunakan dalam pengolahan daging broiler untuk dijadikan ayam goreng atau jenis masakan ayam lainnya, sehingga peran minyak goreng adalah sebagai barang pelengkap atau komplementer dari daging broiler. Hal ini sejalan dengan penelitian Wahyudi (2002) di Jogjakarta serta Rusman dan Suharyanto (2004) di Sulawesi Tenggara.

\section{Harga beras}

Variabel harga beras menunjukkan adanya pengaruh signifikan terhadap permintaan daging broiler di Kota Kendari pada tingkat kepercayaan $95 \%$. Koefisien regresi variabel harga beras adalah sebesar $-0,73$, ini berarti bahwa apabila harga beras meningkat sebesar $1 \%$ sedangkan faktor lain dianggap tetap, maka permintaan ayam broiler akan turun sebesar 0,73\%. Apabila koefisien regresi diartikan elastisitas silang, maka beras termasuk barang komplementer terhadap daging broiler, sehingga apabila terjadi kenaikan harga beras akan mengakibatkan penurunan permintaan atau konsumsi rumah tangga terhadap daging broiler.

Beras merupakan sumber makanan pokok masyarakat Kota Kendari, sedangkan daging broiler merupakan lauk yang biasanya dikonsumsi bersama nasi dalam kehidupan sehari-hari.

\section{Kejadian flu burung (variabel dummy)}

Penyakit Avian Influensa (AI) atau lebih dikenal dengan nama flu burung pertama ditemukan di Kota Kendari berdasarkan uji laboratorium peternakan Balai Besar Veteriner Maros Sulawesi Selatan pada tahun 2005 di Kecamatan Mandonga yang menyerang ayam buras, selanjutnya pada tahun 2006 berturut-turut positif ditemukan di Kecamatan Kendari pada bulan Juli yang menyerang ayam buras, di Kecamatan Baruga pada bulan Agustus yang menyerang ayam buras dan ayam petelur, dan di Kecamatan Abeli pada bulan Desember yang menyerang ayam buras.

Variabel dummy kejadian flu burung tidak menunjukkan adanya pengaruh yang signifikan terhadap jumlah permintaan daging broiler di Kota Kendari, hal ini disebabkan karena di wilayah penelitian penyakit flu burung tidak mewabah seperti yang terjadi di Pulau Jawa dan Pulau Sumatera yang menyebabkan tidak hanya menyerang ribuan ekor unggas tetapi sampai menelan korban jiwa. Penyakit flu burung di Kota Kendari tidak menyerang ayam broiler tetapi hanya menyerang ayam buras dan ayam petelur dalam jumlah yang sedikit.

\section{Prediksi produksi dan konsumsi daging broiler}

Analisis regresi digunakan untuk memprediksi perkembangan total konsumsi maupun produksi daging broiler dari tahun ke tahun, dengan menggunakan data jumlah penduduk, konsumsi per kapita dan produksi daging broiler tahun 1994 sampai tahun 2008, seperti pada gambar.

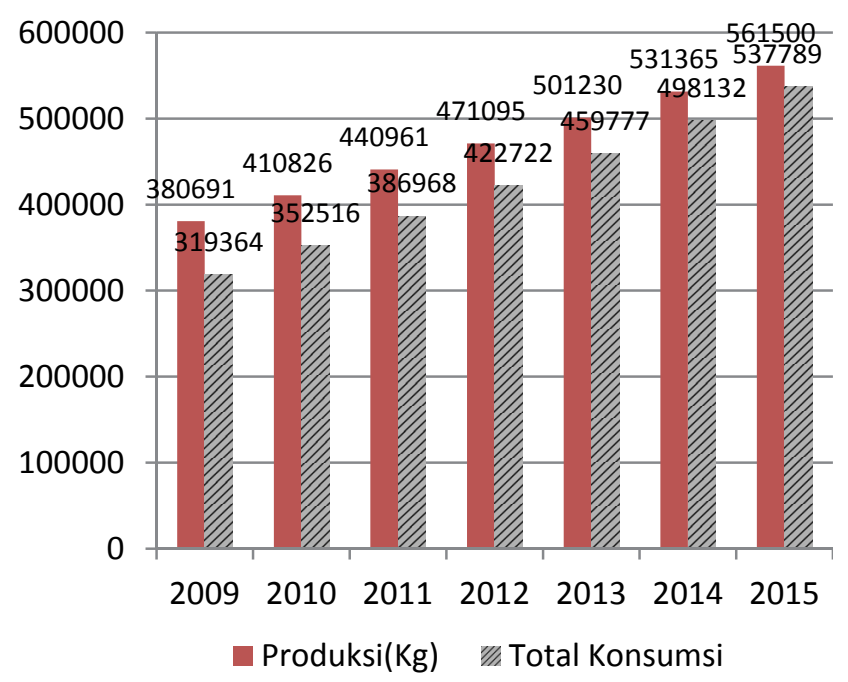

Gambar prediksi produksi dan konsumsi daging broiler di kota Kendari tahun 2009 - 2015 (prediction of production and consumption of broiler in Kendari from 2009 to 2015).

Pada gambar di atas memperlihatkan hasil prediksi produksi dan total konsumsi daging broiler tahun 2009 sampai tahun 2015 menunjukkan bahwa faktor waktu sangat berpengaruh terhadap produksi dan total konsumsi daging broiler. Faktor waktu yang dilihat dari koefisien regresi, memperlihatkan 
hasil yang positif terhadap produksi, jumlah penduduk dan total konsumsi daging broiler, sehingga dapat dikatakan bahwa trend dari produksi dan total konsumsi daging broiler di Kota Kendari cenderung naik seiring dengan bertambahnya waktu, dengan laju peningkatan produksi daging broiler lebih tinggi dari laju peningkatan total konsumsi daging broiler.

Produksi daging broiler di Kota Kendari lebih tinggi dari konsumsi daging broiler, disebabkan banyaknya variasi penyedia bahan makanan sumber protein seperti ikan, kerang-kerangan dan hasil laut lainnya serta kebiasaan pola makan masyarakat kota Kendari adalah mengkonsumsi ikan. Konsumsi ikan pada tahun 2009 berjumlah 31,34 kg/kapita (Dinas Kelautan dan Perikanan, 2009), sedangkan konsumsi daging broiler tahun 2008 sebanyak 1,18 $\mathrm{kg} / \mathrm{kapita}$ (NBM, 2008). Data Badan Pusat Statistik (2007) menyatakan bahwa konsumsi protein hewani masyarakat Kota Kendari tertinggi berasal dari ikan yang mencapai $24,60 \mathrm{gr} / \mathrm{kapita} / \mathrm{hari}$, kemudian telur dan susu sebesar 2,09 gr/kapita/hari serta daging $1,38 \mathrm{gr} / \mathrm{kapita} / \mathrm{hari}$.

Kelebihan produksi daging broiler di Kota Kendari terjadi sejak tahun 2003 dan prediksi sampai tahun 2015, menunjukkan bahwa produksi daging broiler lebih tinggi dari konsumsi daging broiler. Kelebihan produksi daging broiler ini di pasarkan ke kabupaten lain dalam lingkup Provinsi Sulawesi tenggara.

\section{Kesimpulan dan Saran}

\section{Kesimpulan}

Permintaan daging broiler secara bersamasama sangat dipengaruhi oleh jumlah penduduk, pendapatan, harga daging broiler, harga daging sapi, harga daging ayam buras, harga telur, harga ikan bandeng, harga minyak goreng serta harga beras. Elastisitas pendapatan masyarakat Kota Kendari terhadap jumlah permintaan daging broiler bernilai positif dan kurang dari satu, sedangkan elastisitas harga sendiri daging broiler terhadap jumlah permintaan daging broiler bersifat inelastis. Daging broiler secara fungsi dan kegunaan merupakan barang substitusi bagi daging sapi dan ikan bandeng, sedangkan minyak goreng dan beras termasuk barang komplementer. Perkembangan konsumsi daging broiler cenderung mengalami peningkatan seiring dengan meningkatnya jumlah penduduk.

\section{Saran}

Produksi daging broiler di Kota Kendari lebih tinggi dari konsumsi daging broiler. Kelebihan produksi tersebut didistribusikan ke kabupaten/kota lainnya di wilayah Provinsi Sulawesi Tenggara.

\section{Daftar Pustaka}

Badan Pusat Statistik. 2007. Konsumsi Kalori dan Protein Penduduk Indonesia dan Provinsi. Biro Pusat Statistik. Jakarta.

Dinas Kelautan dan Perikanan. 2009. Laporan Tahunan Dinas Kelautan dan Perikanan Kota Kendari Tahun 2009. Pemerintah Kota Kendari.

Gujarati, D. 1999. Ekonometrika Dasar. Terjemahan Sumarno Zain. Cetakan keenam. Erlangga. Jakarta.

NBM. 2008. Neraca Bahan Makanan Provinsi Sulawesi Tenggara. Dinas Pertanian Provinsi Sulawesi Tenggara.

Nurtini, S., Arinto, Koesno, S.P. Syahlani, H. Sasongko, I.G.S. Budisatria, dan T. Wisnumurti. 1998. Studi Tataniaga Daging, Telur dan Susu di Propinsi Daerah Istimewa Yogyakarta. Kerjasama Dinas Peternakan DIY dengan Fakultas Peternakan UGM. Yogyakarta.

Pappas, J.L. dan M. Hirschey. 1995. Ekonomi Manajerial. Terjemahan Edisi Keenam, Jilid I. Binarupa Aksara. Jakarta.

Rusman, M. dan Suharyanto. 2004. SOCA (SocioEconomic of Agriculturre and Agribusiness). Analisis Permintaan Daging Sapi di Provinsi Sulawesi Tenggara. Volume: 4 No. 1.

Saleh, S. 2004. Statistik Deskriptif. Edisi Revisi. UPP AMP YKPN. Yogyakarta.

Soedjana, T.D. 1996. Perkembangan konsumsi daging dan telur di Indonesia. Majalah Pangan No. 29 Vol. VIII. Bogor.

Wahyudi, D.R. 2002. Analisis permintaan daging ayam di propinsi Daerah Istimewa Yogyakarta. Tesis S-2 Program Pasca Sarjana Universitas Gadjah Mada, Yogyakarta. 